\title{
Production response to corn silage produced from normal, brown midrib, or waxy corn hybrids
}

\author{
J. S. Barlow, ${ }^{1}$ J. K. Bernard, ${ }^{2}$ and N. A. Mullis \\ Department of Animal and Dairy Science, University of Georgia, Tifton 31793-5766
}

\begin{abstract}
The objective was to evaluate the nutrient intake and digestibility and milk production response of lactating dairy cows fed diets based on corn silage produced from 3 different types of corn hybrids. Experimental diets contained $36.4 \%$ of the dietary dry matter (DM) from corn silage produced from normal (Agratech 1021, AgraTech Seeds Inc., Atlanta, GA), brown midrib (BMR; Mycogen F2F797, Mycogen Seeds, Indianapolis, IN), or waxy (Master's Choice 590, Master's Choice Hybrids, Ullin, IL) hybrids. Thirty-six multiparous and primiparous Holstein cows $(66 \pm 22 \mathrm{~d}$ in milk, $41 \pm 8$ $\mathrm{kg} / \mathrm{d}$ of milk) were used in an 11-wk completely randomized design trial during the fall of 2009. All cows were fed a diet containing normal corn silage during the first 2 wk of the trial before being assigned to 1 of 3 treatments for the following 9 wk. Data collected during the first 2 wk were used as a covariate in the statistical analysis. No difference was observed in dry matter intake (DMI) among treatments, which averaged $22.6 \mathrm{~kg} / \mathrm{d}$. Milk yield was higher for cows fed BMR $(37.6 \mathrm{~kg} / \mathrm{d})$ compared with waxy $(35.2 \mathrm{~kg} / \mathrm{d})$ but was similar to that of cows fed control $(36.2 \mathrm{~kg} / \mathrm{d})$. Milk fat percentage tended to be lower for cows fed control (3.28\%) compared with those fed BMR (3.60\%) or waxy $(3.55 \%)$ corn silage. Milk protein percentage tended to be lower for cows fed control $(2.79 \%)$ compared with waxy $(2.89 \%)$ but similar to that of those fed BMR (2.85\%). No differences were observed in yield of milk components. Energy-corrected milk (ECM) yield and dairy efficiency (ECM:DMI) did not differ among treatments. Cows fed BMR tended to gain more body weight compared with those fed control and waxy. Results of this trial are consistent with previous reports in which cows fed diets based on corn silage produced from BMR hybrids have higher milk yield compared with those fed other hybrids. Corn silage produced
\end{abstract}

Received January 13, 2012.

Accepted March 31, 2012.

${ }^{1}$ Current address: 1416 N. Grabview St., Stillwater, OK 74075.

${ }^{2}$ Corresponding author: jbernard@uga.edu from the waxy hybrid supported a similar yield of ECM because of higher milk components, but milk yield was not improved compared with the control.

Key words: brown midrib, waxy, corn silage

\section{INTRODUCTION}

Corn silage accounts for the largest portion of forage fed to lactating dairy cows on most dairy farms. Numerous corn hybrid varieties are available for producing silage. Although hybrids were selected for silage based on corn grain yields (Bal et al., 2000), high-yielding grain hybrids are not always the ideal choice for silage production (Coors et al., 1994). The variation in the nutritive content of hybrids (Johnson et al., 1985; Coors, 1996) is usually not taken into consideration when hybrid selection is based solely on grain yield.

Brown midrib (BMR) corn hybrids naturally have lower lignin concentrations and are reported to improve DMI and increase milk yields compared with their isogenic controls (Oba and Allen, 1999). However, BMR corn silage typically has lower DM yields and higher lodging potential (Cherney et al., 1991) than normal hybrids. Based on available reports at the time, Eastridge (1999) reported that BMR hybrids had an average of $10.4 \%$ lower DM yield compared with normal hybrids. When fed to lactating dairy cows, BMR often supports higher DMI because of the higher rate of passage compared with normal hybrids. Oba and Allen (2000a,b) concluded that increasing postruminal starch digestion and efficiency of microbial $\mathrm{N}$ production along with greater DMI and an increased rate of passage might be responsible for higher milk yields when feeding BMR corn silage.

The effect of waxy corn silage on milk production has been evaluated in only a limited number of studies. Akay and Jackson (2001) fed corn silage and grain produced from a waxy corn hybrid to early lactation dairy cows and observed higher yields of milk and FCM compared with that in cows fed diets supplemented with corn silage and grain produced from a normal corn hybrid. Moreira et al. (2000) also reported higher yields of milk and FCM when lactating cows were fed diets based on waxy corn silage compared with diets based 
on conventional corn silage. The starch in waxy hybrids is primarily amylopectin, whereas starch in conventional hybrids is approximately $75 \%$ amylopectin and $25 \%$ amylose. Amylopectin is highly digestible in the rumen (Mohd and Wootton, 1984), which could make waxy corn more beneficial than normal corn hybrids to ruminants.

The objective of this research was to evaluate the nutritive intake and digestibility and milk production of lactating dairy cows fed diets containing $36.4 \%$ of the dietary DM from corn silage produced from normal, brown midrib, or waxy corn hybrids.

\section{MATERIALS AND METHODS}

Corn silage was produced from 3 hybrid varieties planted in the spring of 2009: normal corn hybrid (control; AgraTech 1021, AgraTech Seeds Inc., Atlanta, GA), BMR type (Mycogen F2F797, Mycogen Seeds, Indianapolis, IN), and a waxy type (MC590, Masters Choice Hybrids, Ullin, IL). Corn was planted in Tifton sandy loam soil at a seeding rate of 70,000 plants/ha using strip-tillage methods and was irrigated using dairy waste effluent. Additional fertilizer was applied based on soil tests and recommendations of the University of Georgia. Corn was harvested at half milk line and chopped to a theoretical chop length of $1.9 \mathrm{~cm}$, with a conventional pull-type 2-row harvester without kernel processing. The forages were inoculated (Biotal 40788, Lallemand Animal Nutrition, Milwaukee, WI) and ensiled separately in 2.4-m silage bags for fermentation for approximately $90 \mathrm{~d}$ before the beginning of the trial.

Thirty-six primiparous $(\mathrm{n}=13)$ and multiparous (n $=23)$ early lactation Holstein cows $(66 \pm 22$ DIM, $41 \pm 8 \mathrm{~kg} / \mathrm{d}$ of milk) were used in a completely randomized design experiment. Cows were trained to eat behind Calan doors (American Calan Inc., Northwood, $\mathrm{NH}$ ) before the beginning of the trial. The 11-wk trial included a 2 -wk preliminary period followed by a 9 -wk experimental period. Experimental diets (Table 1) were formulated (605 kg of BW, 90 DIM, $43 \mathrm{~kg} / \mathrm{d}$ milk, $3.5 \%$ milk fat, and $0.06 \mathrm{~kg} / \mathrm{d}$ of BW gain) with $36.4 \%$ of the total DM provided by 1 of the 3 hybrids. During the pretrial period, cows were fed the control hybrid. Data collected during the preliminary period were used as a covariate in the statistical analysis. At the end of the preliminary period, cows within parity were randomly assigned to 1 of the 3 treatments. All protocols used during this trial were approved by the University of Georgia Institutional Animal Care and Use Committee.

Experimental diets were fed once daily at approximately $110 \%$ of the previous daily intake to ensure ad libitum intake. The amounts of each diet offered and refused were recorded daily for each cow. Samples of experimental diets, orts, and dietary ingredients were collected 3 times each week and dried in a forced-air oven at $55^{\circ} \mathrm{C}$ for $72 \mathrm{~h}$ to determine DM. Samples were ground to pass through a 1-mm screen using a Wiley mill (Arthur H. Thomas, Philadelphia, PA) and composited by week. Composite samples underwent analysis of DM, ash (AOAC, 2000), CP (Leco FP-528 Nitrogen Analyzer, St. Joseph, MI), ADF (AOAC, 2000), NDF (Van Soest et al., 1991), starch (Hall, 2009), sugar (Dubois et. al., 1956), ether extract (AOAC, 2000), and minerals (AOAC, 2000).

Fermentation end-product concentrations of the experimental silages were determined using the filtrate of a 25 -g wet sample blended with $200 \mathrm{~mL}$ of distilled water. Sample $\mathrm{pH}$ was determined using $30 \mathrm{~mL}$ of the extract introduced to a Mettler DL12 Titrator (Mettler-Toledo Inc., Columbus, $\mathrm{OH}$ ) and titrated with 0.1 $N \mathrm{NaOH}$ to a $\mathrm{pH}$ of 6.5 . Ammonia-N concentrations were determined by introducing a dilute sample $(25 \mathrm{~mL}$ of extract and $75 \mathrm{~mL}$ of deionized water) to a Labconco

Table 1. Ingredient composition of experimental diets containing corn silage produced from normal (control), brown midrib (BMR), or waxy corn hybrids

\begin{tabular}{|c|c|c|c|}
\hline Ingredient & Control & BMR & Waxy \\
\hline Normal corn silage & 36.39 & - & - \\
\hline BMR corn silage & - & 36.39 & - \\
\hline Waxy corn silage & - & - & 36.39 \\
\hline Ryegrass silage & 7.87 & 7.87 & 7.87 \\
\hline Alfalfa hay & 7.87 & 7.87 & 7.87 \\
\hline Brewers grain wet & 12.78 & 12.78 & 12.78 \\
\hline Ground corn & 17.70 & 17.70 & 17.70 \\
\hline Soybean hulls, pelleted & 5.51 & 5.51 & 5.51 \\
\hline Megalac $^{1}$ & 1.00 & 1.00 & 1.00 \\
\hline Soybean meal $47.5 \%$ CP & 4.54 & 4.54 & 4.54 \\
\hline Prolak $^{2}$ & 3.62 & 3.62 & 3.62 \\
\hline Potassium-magnesium-sulfate & 0.20 & 0.20 & 0.20 \\
\hline Limestone & 0.43 & 0.43 & 0.43 \\
\hline Dicalcium phosphate & 0.20 & 0.20 & 0.20 \\
\hline Sodium bicarbonate & 0.59 & 0.59 & 0.59 \\
\hline Magnesium oxide & 0.22 & 0.22 & 0.22 \\
\hline Availa- $4^{3}$ & 0.04 & 0.04 & 0.04 \\
\hline Salt & 0.22 & 0.22 & 0.22 \\
\hline Potassium carbonate & 0.20 & 0.20 & 0.20 \\
\hline Diamond V XP yeast culture ${ }^{4}$ & 0.25 & 0.25 & 0.25 \\
\hline Trace mineral-vitamin premix ${ }^{5}$ & 0.16 & 0.16 & 0.16 \\
\hline Rumensin $3 \%^{6}$ & 0.24 & 0.24 & 0.24 \\
\hline
\end{tabular}

${ }^{1}$ Calcium salts of long-chain fatty acids (Church \& Dwight Co. Inc., Princeton, NJ).

${ }^{2}$ Animal-marine protein blend (H. J. Baker \& Bro. Inc., Stamford, $\mathrm{CT})$.

${ }^{3}$ Zinpro Corp. (Eden Prairie, MN).

${ }^{4}$ Diamond V Mills (Cedar Rapids, IA).

${ }^{5}$ Mineral-vitamin premix contained (DM basis): $26.1 \% \mathrm{Ca} ; 0.38 \% \mathrm{Mg}$; $1.76 \% \mathrm{~S} ; 144 \mathrm{mg} / \mathrm{kg}$ of $\mathrm{Co} ; 9,523 \mathrm{mg} / \mathrm{kg}$ of $\mathrm{Cu} ; 1,465 \mathrm{mg} / \mathrm{kg}$ of $\mathrm{Fe}$; $842 \mathrm{mg} / \mathrm{kg}$ of I; $28,617 \mathrm{mg} / \mathrm{kg}$ of Mn; $220 \mathrm{mg} / \mathrm{kg}$ of Se; $25,343 \mathrm{mg} / \mathrm{kg}$ of $\mathrm{Zn} ; 4,210,830 \mathrm{IU} / \mathrm{kg}$ of vitamin A; 1,684,330 IU $/ \mathrm{kg}$ of vitamin D; $21,045 \mathrm{IU} / \mathrm{kg}$ of vitamin $\mathrm{E}$.

${ }^{6}$ Elanco Animal Health (Indianapolis, IN). 
Rapidstill II model 65200 analyzer (Labconco, Kansas City, MO) and titrating with $0.1 \mathrm{~N} \mathrm{HCl}$. Lactic acid concentrations were determined by measuring racemic lactate using YSI 2700 Select Biochemistry Analyzer (YSI Inc., Yellow Springs, OH) on a sample of equal parts extract and deionized water and multiplying the value by 2 for total lactic acid. Concentrations of acetic, propionic, butyric, and isobutyric acids were determined using a $3-\mathrm{mL}$ sample of extract filtered through a $0.2-\mu \mathrm{m}$ polyvinylidene fluoride GD/X Whatman filter membrane (Whatman, Piscataway, NJ). A $0.1-\mu \mathrm{L}$ subsample was then injected into a Perkin Elmer AutoSystem gas chromatograph (Perkin Elmer, Shelton, CT) using a Restek column packed with Stabilwax-DA (Restek, Bellefonte, PA).

Cows were milked twice daily at 0400 and $1600 \mathrm{~h}$. Daily milk yields for each cow were recorded electronically (Alpro, DeLaval, Kansas City, MO). Milk samples were collected from consecutive p.m. and a.m. milkings once each week throughout the trial for analysis of milk fat, protein, and somatic cell concentrations by midinfrared spectrophotometric analysis with a Foss 4000 instrument (Foss North America, Eden Prairie, MN; Dairy One Cooperative, Ithaca, NY). Individual BW was recorded following the p.m. milking on 3 consecutive days at the end of the pretrial period and at the end of the experimental period. To minimize variation, BW was recorded immediately after the p.m. milking, before allowing access to feed or water.

Fecal grab samples were collected from all cows during the last $4 \mathrm{~d}$ of wk 9 of the experimental period to determine nutrient digestibility. Samples were collected every $12 \mathrm{~h}$ and the collection time advanced by $4 \mathrm{~h}$ each day. Fecal samples were dried in a forced-air oven at $55^{\circ} \mathrm{C}$, ground to pass through a $1-\mathrm{mm}$ screen using a Wiley mill, and composited by cow. Samples were analyzed for DM, ash, NDF, ADF, CP, and ether extract as described previously. Indigestible ADF was utilized as a marker for determination of apparent digestibility by incubating triplicate samples for $144 \mathrm{~h}$ and analyzing the residue for ADF according to procedures outlined by Cochran et al. (1986). Nutrient concentrations of the experimental diets were calculated using CPM-Dairy (Boston et al., 2000) after inputting chemical analysis information for individual ingredients. The amount of feed offered and refused and corresponding chemical analysis of diets and orts during wk 9 was used to calculate digestibility coefficients.

Weekly DMI, milk yield, and composition data were subjected to analysis of covariance using the PROC MIXED procedures of SAS (SAS Institute Inc., Cary, NC). Data collected during the pretrial period were used as a covariate for statistical analysis. The model included the effects of covariate, week, treatment, interaction of treatment by week, and error. Cow within treatment was included as a random effect and week as a repeated effect. When significance was observed $(P<$ 0.05 ), the PDIFF option was used for means separation.

Nutrient intake and digestibility data measured in wk 9 and BW data were subjected to ANOVA using the PROC GLM procedures of SAS (SAS Institute Inc.). The model included the effects of cow, treatment, and error. When significance was observed $(P<0.05)$, the PDIFF option was used for mean separation.

\section{RESULTS AND DISCUSSION}

The nutrient composition of the experimental silages is presented in Table 2. The waxy silage contained less NDF and ADF than the BMR and control silages. Akay and Jackson (2001) also reported lower concentrations of NDF and ADF in waxy corn silage compared with conventional corn silage. Starch concentration was higher in waxy $(35.06 \%)$ relative to BMR and control (27.78\% and $29.29 \%$, respectively) silages. Brown midrib corn silage has been reported to have lower levels of starch compared with normal hybrids (Bal et al., 2000; Ballard et al., 2001; Kung et al., 2008). Lignin concentrations were lower for BMR, as expected. The forage was well preserved as indicated by the $\mathrm{pH}$ of the resulting silages. Concentrations of lactic acid were higher and propionic acid lower in BMR compared with either control or waxy.

Table 2. Chemical composition (mean \pm SD; \% of DM unless otherwise noted) of corn silage harvested from normal (control), brown midrib (BMR), or waxy corn hybrids

\begin{tabular}{lrrr}
\hline Item & \multicolumn{1}{c}{ Control } & \multicolumn{1}{c}{ BMR } & \multicolumn{1}{c}{ Waxy } \\
\hline DM, \% & $30.88 \pm 1.36$ & $29.22 \pm 2.09$ & $31.09 \pm 1.66$ \\
CP & $8.71 \pm 0.15$ & $9.02 \pm 0.25$ & $8.52 \pm 0.42$ \\
ADF & $27.09 \pm 2.47$ & $26.02 \pm 1.75$ & $24.36 \pm 1.60$ \\
NDF & $42.81 \pm 3.26$ & $43.38 \pm 2.39$ & $38.58 \pm 2.08$ \\
Lignin & $3.37 \pm 0.42$ & $2.04 \pm 0.29$ & $2.97 \pm 0.25$ \\
Ether extract & $3.59 \pm 0.65$ & $3.06 \pm 0.31$ & $3.34 \pm 0.31$ \\
Ash & $4.67 \pm 0.25$ & $4.68 \pm 0.25$ & $4.13 \pm 0.26$ \\
Starch & $29.29 \pm 2.65$ & $27.78 \pm 2.44$ & $35.06 \pm 3.30$ \\
Sugar & $1.29 \pm 0.26$ & $1.44 \pm 0.30$ & $1.24 \pm 0.19$ \\
Calcium & $0.21 \pm 0.01$ & $0.22 \pm 0.01$ & $0.19 \pm 0.01$ \\
Phosphorus & $0.27 \pm 0.01$ & $0.27 \pm 0.01$ & $0.27 \pm 0.02$ \\
Magnesium & $0.16 \pm 0.01$ & $0.17 \pm 0.01$ & $0.14 \pm 0.01$ \\
Potassium & $1.47 \pm 0.04$ & $1.53 \pm 0.09$ & $1.39 \pm 0.10$ \\
pH & $3.90 \pm 0.10$ & $3.86 \pm 0.10$ & $4.02 \pm 0.07$ \\
Lactic acid & $3.23 \pm 0.83$ & $4.99 \pm 1.13$ & $2.89 \pm 0.62$ \\
Acetic acid & $4.84 \pm 0.83$ & $3.06 \pm 0.90$ & $3.97 \pm 1.66$ \\
Propionic acid & $0.93 \pm 0.55$ & $0.33 \pm 0.18$ & $1.03 \pm 0.68$ \\
Isobutyric acid & $0.01 \pm 0.00$ & $0.01 \pm 0.00$ & $0.01 \pm 0.00$ \\
Total VFA & $9.02 \pm 0.71$ & $8.37 \pm 1.72$ & $7.89 \pm 1.94$ \\
Ammonia-N & $0.99 \pm 0.11$ & $1.00 \pm 0.14$ & $1.02 \pm 0.16$ \\
\hline
\end{tabular}


Table 3. Chemical composition (\% of DM unless otherwise noted) of experimental diets based on corn silage produced from normal (control), brown midrib (BMR), or waxy corn hybrids

\begin{tabular}{lrrr}
\hline Item & Control & BMR & Waxy \\
\hline DM, \% & 40.87 & 40.00 & 40.60 \\
CP & 17.20 & 17.33 & 17.58 \\
ADF & 20.74 & 20.06 & 19.27 \\
NDF & 40.71 & 39.80 & 38.14 \\
Ash & 6.97 & 6.97 & 6.83 \\
Starch & 25.85 & 25.30 & 27.95 \\
Ether extract & 4.76 & 4.57 & 4.67 \\
NE $_{\mathrm{L}},{ }^{1}$ Mcal/kg & 1.76 & 1.76 & 1.79 \\
\hline
\end{tabular}

${ }^{1}$ Calculated using ingredient analysis in CPM-Dairy (Boston et al., 2000).

The DM, CP, and ADF concentrations of the experimental diets were similar (Table 3 ). The waxy diet had lower NDF compared with control and BMR diets, which is consistent with the NDF concentration of the respective silage. Starch concentrations were slightly higher for waxy, in agreement with the observations of Akay and Jackson (2001).

No differences were observed in DMI among treatments (Table 4). Eastridge (1999) reported increased DMI for cows fed diets based on brown midrib corn silage. The NDF fraction of BMR is more readily digestible in the rumen (Oba and Allen, 1999), which has been suggested to increase passage rate and reduce rumen fill, thus supporting greater DMI compared with conventional corn silage (Oba and Allen, 2000b).

Milk yield was greater $(P<0.05)$ for cows fed BMR compared with waxy. Castro et al. (2010) did not observe any difference in milk yield when cows were fed corn silage-based diets produced from either a brown midrib or normal hybrid. The absence of a difference in milk yield between waxy and control is in contrast to the increased milk yield reported by Akay and Jackson (2001) and Moreira et al. (2000). Milk fat percentage tended to be higher $(P=0.10)$ for cows fed BMR or waxy compared with control. Milk protein percentage $(P=0.07)$ tended to be higher for cows fed waxy compared with control. In contrast, previous trials have not observed any difference in milk fat and protein percentage (Moreira et al., 2000; Akay and Jackson, 2001). No differences were observed in yields of milk fat, milk protein, or ECM. Efficiency of milk production (ECM:DMI) did not differ among treatments and averaged 1.40. Cows fed BMR tended $(P=0.10)$ to gain more BW during the trial compared with cows fed control or waxy.

Nutrient intake and digestibility during wk 9 is presented in Table 5. Intake of DM, CP, and ADF was not different among treatments. Intake of NDF tended $(P$ $=0.08)$ to be lower and ether extract intake was lower $(P<0.0001)$ for cows fed waxy compared with that measured for BMR or control. Total-tract digestibility of $\operatorname{NDF}(P=0.05)$ and $\operatorname{ADF}(P=0.03)$ was greater for BMR compared with waxy or control. Digestibility of ether extract was lower $(P=0.003)$ for waxy compared with control and BMR.

Oba and Allen (1999) also reported improvements in total-tract digestibility of NDF and ADF when feeding BMR corn silage compared with control silage. Those authors suggested that the NDF fraction of BMR corn silage undergoes hydrolysis more rapidly, thus reducing rumen fill and allowing greater DMI. However, an increased rate of passage is often observed with higher DMI, which could reduce the digestibility of NDF (Allen and Mertens, 1988). Akay and Jackson (2001) did not observe differences in NDF or ADF digestibility for diets based on either waxy or NutriDense (BASF Plant Science, Research Triangle Park, NC) hybrids. It has been reported that microorganisms digest starch before digesting fiber (El-Shazly et al., 1961). McCarthy et al. (1989) reported that increasing the proportion of ruminally available starch in the diet has negative effects on the digestibility of NDF and ADF. This might

Table 4. Dry matter intake, milk yield, and composition of lactating dairy cows fed diets based on corn silage produced from normal (control), brown midrib (BMR), or waxy corn hybrids

\begin{tabular}{lccccc}
\hline Item & Control & BMR & Waxy & SE & $P$-value \\
\hline DMI, kg/d & 22.4 & 23.0 & 22.6 & 0.7 & 0.84 \\
Milk, kg/d & $36.2^{\text {ab }}$ & $37.6^{\mathrm{a}}$ & $35.1^{\mathrm{b}}$ & 0.6 & 0.03 \\
Fat, \% & $3.28^{\mathrm{c}}$ & $3.60^{\mathrm{d}}$ & $3.55^{\mathrm{d}}$ & 0.05 & 0.10 \\
Fat, $\mathrm{kg} / \mathrm{d}$ & 1.19 & 1.35 & 1.25 & 0.05 & 0.23 \\
Protein, \% & $2.79^{\mathrm{c}}$ & $2.85^{\mathrm{cd}}$ & $2.89^{\mathrm{d}}$ & 0.01 & 0.07 \\
Protein, kg/d & 1.01 & 1.07 & 1.02 & 0.03 & 0.15 \\
ECM, kg/d & 30.7 & 32.4 & 30.7 & 0.82 & 0.17 \\
Efficiency & 1.35 & 1.43 & 1.38 & 0.02 & 0.46 \\
Initial BW, kg & 617.0 & 616.1 & 628.2 & 21.7 & 0.91 \\
Change in BW, kg & $21.0^{\mathrm{c}}$ & $36.9^{\mathrm{d}}$ & $24.4^{\mathrm{c}}$ & 5.2 & 0.10 \\
\hline
\end{tabular}

${ }^{\mathrm{a}, \mathrm{b}}$ Means with different superscripts in the same row differ $(P<0.05)$.

${ }^{\mathrm{c}, \mathrm{d}}$ Means with different superscripts in the same row differ $(P<0.10)$.

${ }^{1} \mathrm{ECM}: \mathrm{DMI}$. 
Table 5. Nutrient intake and digestibility of cows fed diets based on corn silage produced from normal (control), brown midrib (BMR), or waxy corn hybrids

\begin{tabular}{lccccc}
\hline Item & Control & BMR & Waxy & SE & $P$-value \\
\hline Intake, kg/d & & & & & \\
DM & 23.86 & 23.52 & 21.76 & 0.97 & 0.26 \\
CP & 4.2 & 4.13 & 3.94 & 0.17 & 0.51 \\
NDF & $8.32^{\mathrm{c}}$ & $8.38^{\mathrm{c}}$ & $7.34^{\mathrm{d}}$ & 0.35 & 0.08 \\
ADF & 5.16 & 5.09 & 4.57 & 0.21 & 0.11 \\
Starch & 6.4 & 6.08 & 6.13 & 0.25 & 0.62 \\
Ether extract & $1.23^{\mathrm{a}}$ & $1.22^{\mathrm{a}}$ & $0.94^{\mathrm{b}}$ & 0.05 & $<0.0001$ \\
Digestibility, \% & & & & & \\
DM & 67.04 & 68.2 & 66.1 & 1.46 & 0.62 \\
CP & 70.56 & 70.43 & 70.16 & 1.6 & 0.98 \\
NDF & $47.5^{\mathrm{b}}$ & $52.71^{\mathrm{a}}$ & $46.04^{\mathrm{b}}$ & 1.86 & 0.05 \\
ADF & $54.98^{\mathrm{b}}$ & $58.6^{\mathrm{a}}$ & $53.52^{\mathrm{b}}$ & 1.28 & 0.03 \\
Starch & 96.36 & 94.8 & 94.78 & 0.77 & 0.25 \\
Ether extract & $84.39^{\mathrm{a}}$ & $86.25^{\mathrm{a}}$ & $79.66^{\mathrm{b}}$ & 1.27 & 0.003 \\
\hline
\end{tabular}

${ }^{\mathrm{a}, \mathrm{b}}$ Means with different superscripts in the same row differ $(P<0.05)$.

${ }^{\mathrm{c}, \mathrm{d}}$ Means with different superscripts in the same row differ $(P<0.10)$.

explain the lower fiber digestion observed when feeding waxy, which contained higher concentrations of starch than either control or BMR.

\section{CONCLUSIONS}

The choice of corn hybrid used for silage production can affect the performance of lactating dairy cows. In the current trial, diets supplemented with BMR resulted in improved milk yield because of greater NDF and ADF digestibility. Feeding waxy silage tended to result in increased concentrations of milk fat and protein compared with control, but did not affect intake, milk yield, or nutrient digestibility. All hybrids supported similar yield of ECM and efficiency. The corn silage produced from the hybrids in the current trial was managed to minimize any potential differences related to environmental or management effects, which are important considerations when selecting a hybrid for corn silage production.

\section{ACKNOWLEDGMENTS}

The authors extend their appreciation to the University of Georgia Animal and Dairy Science farm crew for producing and harvesting corn hybrids, to the dairy research center staff for assistance with animal care and management, and to Melissa Tawzer (Department of Animal and Dairy Science, University of Georgia) for assistance with chemical analysis.

\section{REFERENCES}

Akay, V., and J. A. Jackson Jr. 2001. Effects of NutriDense and waxy corn hybrids on the rumen fermentation, digestibility, and lactational performance of dairy cows. J. Dairy Sci. 84:1698-1706.
Allen, M. S., and D. R. Mertens. 1988. Evaluating constraints on fiber digestion by rumen microbes. J. Nutr. 118:261-270.

AOAC. 2000. Official Methods of Analysis. 17th ed. Association of Official Analytical Chemists, Arlington, Va.

Bal, M. A., R. D. Shaver, H. Al-Jobeile, J. G. Coors, and J. G. Lauer. 2000. Corn silage hybrid effects on intake, digestion, and milk production by dairy cows. J. Dairy Sci. 83:2849-2858.

Ballard, C. S., E. D. Thomas, E. S. Tsang, P. Mandebvu, C. J. Sniffen, M. I. Endres, and M. P. Carter. 2001. Effect of corn silage hybrid on dry matter yield, nutrient composition, in vitro digestion, intake by dairy heifers, and milk production by dairy cows. J. Dairy Sci. 84:442-452.

Boston, R., D. Fox, C. Sniffen, E. Janczewski, R. Munson, and W. Chalupa. 2000. The conversion of a scientific model describing dairy cow nutrition and production to an industry tool: The CPM-Dairy project. Pages 361-377 in Modeling Nutrition of Farm Animals. J. P. McNamara, J. France, and D. E. Beever, ed. CAB International, Wallingford, UK

Castro, J. J., J. K. Bernard, N. A. Mullis, and R. B. Eggleston. 2010. Brown midrib corn silage and Tifton 85 bermudagrass in rations for early-lactation cows. J. Dairy Sci. 93:2143-2152.

Cherney, J. H., D. J. R. Cherney, D. E. Akin, and J. D. Axtell. 1991 Potential of brown midrib, low lignin mutants for improving forage quality. Adv. Agron. 46:157-198.

Cochran, R. C., D. C. Adams, J. D. Wallace, and M. L. Galyean. 1986 Predicting digestibility of different diets with internal markers: Evaluation of four potential markers. J. Anim. Sci. 63:1476-1483.

Coors, J. G. 1996. Findings of the Wisconsin corn silage consortium Pages 20-28 in Proc. Cornell Nutr. Conf. for Feed Manuf. Rochester, NY. Cornell Univ., Ithaca, NY.

Coors, J. G., P. R. Carter, and R. B. Hunter. 1994. Silage corn. Pages 305-340 in Specialty Corns. A. R. Hallauer, ed. CRC Press, Boca Raton, FL.

Dubois, M., K. A. Gilles, J. K. Hamilton, P. A. Rebers, and F. Smith. 1956. Colorimetric method for determination of sugars and related substances. Anal. Chem. 28:350-356.

Eastridge, M. L. 1999. Brown midrib corn silage. Pages $179-190$ in Proc. Tri-State Dairy Nutrition Conf. The Ohio State University, Columbus.

El-Shazly, K., A. Dehority, and R. R. Johnson. 1961. Effect of starch on the digestion of cellulose in vitro and in vivo by rumen microorganisms. J. Anim. Sci. 20:268-273.

Hall, M. B. 2009. Analysis of starch, including maltooligosaccharides, in animal feeds: A comparison of methods and a recommended method for AOAC collaborative study. J. AOAC Int. 92:42-49.

Johnson, J. C., Jr., W. G. Monson, and W. T. Pettigrew. 1985. Variation in nutritive value of corn hybrids for silage. Nutr. Rep. Int 32:953-958. 
Kung, L., Jr., B. M. Moulder, C. M. Mulrooney, R. S. Teller, and R. J. Schmidt. 2008. The effect of silage cutting height on the nutritive value of a normal corn silage hybrid compared with brown midrib corn silage fed to lactating cows. J. Dairy Sci. 91:1451-1457.

McCarthy, R. D., Jr., T. H. Klusmeyer, J. L. Vicini, J. H. Clark, and D. R. Nelson. 1989. Effects of source of protein and carbohydrates on ruminal fermentation and passage of nutrients to the small intestine of lactating cows. J. Dairy Sci. 72:2002-2016.

Mohd, B. M. N., and M. Wootton. 1984. In vitro digestibility of hydroxypropyl maize, waxy maize and high amylose maize starches. Starch/Stärke 36:273-275.

Moreira, V. R., J. Jimmink, L. D. Satter, J. L. Vicini, and G. F. Hartnell. 2000. Effect of corn silage containing high oil, waxy, multileaf, or bm3 corn genetics on feed intake, milk yield, and milk composition of dairy cows. J. Dairy Sci. 78(Suppl. 1):110. (Abstr.)
Oba, M., and M. S. Allen. 1999. Effects of brown midrib 3 mutation in corn silage on dry matter intake and productivity of high yielding dairy cows. J. Dairy Sci. 82:135-142.

Oba, M., and M. S. Allen. 2000a. Effects of brown midrib 3 mutation in corn silage on productivity of dairy cows fed two concentration of dietary neutral detergent fiber: Part 1. Feeding behavior and nutrient utilization. J. Dairy Sci. 83:1333-1341.

Oba, M., and M. S. Allen. 2000b. Effects of brown midrib 3 mutation in corn silage on productivity of dairy cows fed two concentration of dietary neutral detergent fiber: Part 3. Digestibility and microbial efficiency. J. Dairy Sci. 83:1350-1358.

Van Soest, P. J., J. B. Robertson, and B. A. Lewis. 1991. Methods for dietary fiber, neutral detergent fiber, and nonstarch polysaccharides in relation to animal nutrition. J. Dairy Sci. 74:3583-3597. 